\section{Oligopsony and Minimum Wages}

\section{Hernán Vallejo}

\section{Documento CEDE}

$$
\text { \#13 }
$$


(C) 2021, Universidad de los Andes, Facultad de Economía, CEDE. Calle 19A No. 1 - 37 Este, Bloque W. Bogotá, D. C., Colombia Teléfonos: 3394949- 3394999, extensiones 2400, 2049, 2467

infocede@uniandes.edu.co

http://economia.uniandes.edu.co

Impreso en Colombia - Printed in Colombia

La serie de Documentos de Trabajo CEDE se circula con propósitos de discusión y divulgación. Los artículos no han sido evaluados por pares ni sujetos a ningún tipo de evaluación formal por parte del equipo de trabajo del CEDE. El contenido de la presente publicación se encuentra protegido por las normas internacionales y nacionales vigentes sobre propiedad intelectual, por tanto su utilización, reproducción, comunicación pública, transformación, distribución, alquiler, préstamo público e importación, total o parcial, en todo o en parte, en formato impreso, digital o en cualquier formato conocido o por conocer, se encuentran prohibidos, y sólo serán lícitos en la medida en que se cuente con la autorización previa y expresa por escrito del autor o titular. Las limitaciones y excepciones al Derecho de Autor, sólo serán aplicables en la medida en que se den dentro de los denominados Usos Honrados (Fair use), estén previa y expresamente establecidas, no causen un grave e injustificado perjuicio a los intereses legítimos del autor o titular, y no atenten contra la normal explotación de la obra.

Universidad de los Andes | Vigilada Mineducación Reconocimiento como Universidad: Decreto 1297 del 30 de mayo de 1964. Reconocimiento personería jurídica: Resolución 28 del 23 de febrero de 1949 Minjusticia.

\section{Documento CEDE}

Los documentos CEDE son producto de las investigaciones realizadas por al menos un profesor de planta de la Facultad de Economía o sus investigadores formalmente asociados. 


\title{
Oligopsony and Minimum Wages
}

\author{
Hernán Vallejo* \\ Universidad de los Andes \\ Facultad de Economía \\ Bogotá D.C., Colombia \\ hvallejo@uniandes.edu.co
}

\begin{abstract}
This article presents a model of oligopsony. It considers different conjectural variations that cover the whole range between the extreme cases of monopsony and perfect competition, such as Collusion, Threat, Cournot, Stackelberg, and Bertrand, and compares them in terms of prices, quantities, profits, mark-down, price elasticity of supply and welfare. It also considers the impact of minimum wages, under the different conjectures analyzed.
\end{abstract}

JEL Classification: C72, J21, J38, J48.

Keywords: Oligopsony, Collusion, Threat, Cournot, Stackelberg, Bertrand, mark-down, minimium wages

*The author thanks Santiago Neira for his feedback. All remaining errors belong to the author. 


\title{
El oligopsonio y los salarios mínimos
}

\author{
Hernán Vallejo ${ }^{1}$ \\ Universidad de los Andes \\ Facultad de Economía \\ Bogotá D.C., Colombia
}

hvallejo@uniandes.edu.co

Este artículo presenta un modelo de oligopsonio. Considera diferentes variaciones conjeturales que cubren todo el rango entre los casos extremos de monopsonio y competencia perfecta, como Colusion, Amenaza, Cournot, Stackelberg y Bertrand, y las compara en términos de precios, cantidades, ganancias, mark-down, elasticidad salario de la oferta y el bienestar. También considera el impacto de los salarios mínimos, bajo las diferentes conjeturas analizadas.

Clasificaciones JEL: C72, J21, J38, J48.

Palabras claves: Oligopsonio, Colusión, Amenaza, Cournot, Stackelberg, Bertrand, mark-down, salarios mínimos.

\footnotetext{
${ }^{1}$ El autor agradece a Santiago Neira por su retroalimentación. Todos los errores que quedan, son del autor.
} 


\section{Introduction}

This article presents a model of oligopsony. Oligopsony can describe the input markets of a range of industries, such as large scale retail, aerospace, automobile production, legal drug development, oil rigs and mining in far areas, and agricultural production processing, among others.

When there is oligopsony, firms may have market power and apply a mark-down, paying for their inputs less than their marginal product.

The objective in this article is to develop a simple model of oligopsony, in order to illustrate some of the key insights of that market structure and show how its equilibrium may shift depending on the way firms interact, that is, depending on their conjectural variations. Such conjectural variations are the beliefs that firms have on how their competitors will react to their actions, for example in terms of output, employment, prices and wages.

Although in real life there may be infinite equilibria in an oligopsony, this article considers six standard conjectural variations, that yield equilibria that cover the whole range between the extremes of monopsony and perfect competition, and some intermediate cases.

In order to make it easier to compare the different equilibria obtained, all the models are estimated with the same and simple production function, and the same and simple labor supply curve.

\section{Previous literature}

Theories of oligopsony have been studied by different authors. According to Bhashkar et al. (2002), ologopsony and monopsonistic competition are the market structures that best describe the labor markets in the real world.

Rogers et al. (1994) argue that the dismissive treatment that the economics profession has given to buyer market power, is not reasonable when considering raw agricultural markets, which are likely to be structural oligopsonies, characterized by lots of farmers, and few buyers, and large farm-retail spreads. They also point out that the lack of public 
intervention leads to farmers trying to organize themselves, and buyers trying to divide and conquer farmers, by using discrimination.

OECD (1998) argues that large multi-product retailers could enjoy substantial buyer power, despite not having a dominant position in their retail market shares, as buyers or sellers. They suggest countries can use merger reviews; apply laws against discrimination, horizontal agreements, and resale price maintenance; and encourage complaints, in order to keep sufficient competition, both upstream and downstream. They also warn against applying policies that result in a reduction of effective competition in these markets.

Manning (2003) presents models of monopsony and oligopsony and argues that in those contexts, raising wages to equal the marginal product, is not necessarily efficient. He points out that in monopsonistic markets, wages are explained by the marginal product of labor, but also by the reservation wage, the job offer arrival rates and the job destruction rates. He also argues that the higher the share of recruits from non-employment, the more monopsonistic is the labor market.

Atkinson et al. (1989) find evidence of monopsony behaviour in the market of coal and its transportation. Bergman et al. (1995) design a test for oligopsony power and apply it to the Swedish pulpwood market, finding that the degree of market power changes across time. Varian (2010) presents a model of oligopoly, while considering and comparing the impacts on equilibrium of different conjectural variations.

However, most textbooks and most academic programs in undergraduate and graduate economics, cover perfect competition and monopsony in labor markets, but do not cover oligopsony and monopsonistic competition, as part of their core.

\section{A Model of the Oligopsony}

In order to present the model of oligopsony proposed in this article, some general assumptions are used throughout the different conjectures considered here. Those assumptions are presented first, followed by the equilibria under Collusion, Threat, Cournot, Stackelbeg, and Bertrand.

Emphasis will be placed on obtaining simple algebraic results, that can be summarized 
and compared later on, in order to obtain an analytical idea of the way oligopsony works, and what are its consequences.

It is important to study different conjectural variations under oligopsony, since as Bergman et al. (1995) point out, the interactions between firms, may vary across time. They may also vary across markets.

\subsection{General Assumptions}

For all of the conjectural variations considered in this article, focus will be placed on labor markets, as a key input. It will be assumed that there are many homogeneous suppliers of work, who are price takers. There are two identical firms $A$ and $B$, that hire workers and have no fixed costs, since this article concentrates on the impacts of the conjectural variations, and not on the role of economies of scale.

In terms of production, both firms use only labor and have the following linear production function:

$$
q_{i}=f\left(l_{i}\right)=b l_{i}
$$

The marginal product of labor is thus constant: $M g P_{l_{i}}=b$

Note that oligoposony has no market demand of labor. Producers have market power and maximize profits. As such, they pay the minimum price that they can for the labor that they hire, and that price is given by the supply curve. Thus, in oligopsony, it is impossible to find a relationship between labor hired and wages paid, that is independent of the supply of labor and thus, there is no labor demand in oligopsony (and neither in monopsony and monopsonistic competition, for that matter).

The market labor supply curve is also linear: $w=d+a L$

The market wage rate depends on the labor hired by firms $A$ and $B$ :

$w=d+a\left(l_{A}+l_{B}\right)$

Output of firms $A$ and $B$ is sold in a competitive market, and the output unit price is $p=1$

The three parameters of the model, $a, b$, and $d$, are assumed to be positive. Furthermore, the market existence condition implies that $b>d$. Otherwise, the market would collapse. 


\subsection{Collusion}

Collusion (or cartel), refers to firms that cooperate with each other as buyers of labor, in order to extract maximum surplus from their workers. Collusion is the only cooperative equilibrium considered in this article.

If the firms want to maximize profits and cooperate, they act as a profit maximizing monoposonist. If there was something different that the colluding firms could do to have higher profits than a monopsonist, the monopsonist would not be maximizing its profits.

The profit maximization under Collusion can be written as:

$$
\begin{gathered}
\Pi=b L-[d+a L] L \\
\frac{\partial \Pi}{\partial L}=b-d-2 a L=0 \\
L=\frac{b-d}{2 a}>0
\end{gathered}
$$

Replacing $L$ in the supply curve:

$$
w=\frac{b+d}{2}>0
$$

There is a mark-down $(M D)$ in Collusion, since the wage is below the marginal product of labor:

$$
\begin{aligned}
& M D=\left[\frac{b-\frac{b+d}{2}}{b}\right] \\
& M D=\frac{b-d}{2 b}>0
\end{aligned}
$$

The price elasticity of supply at equilibrium is:

$$
\eta=\frac{1}{a} \frac{\frac{b+d}{2}}{\frac{b-d}{2 a}}
$$




$$
\eta=\frac{b+d}{b-d}>0
$$

Since the marginal product of labor is assumed constant, for simplicity, there is no $a$ priori mechanism to allocate labor between firms. However, in a symmetric equilibrium:

$$
\begin{gathered}
l_{A}=l_{B}=\frac{b-d}{4 a}>0 \\
\Pi_{A}=\Pi_{B}=\left[b-\left[\frac{b+d}{2}\right]\right] \frac{b-d}{4 a} \\
\Pi_{A}=\Pi_{B}=\frac{(b-d)^{2}}{8 a}>0 \\
\Pi=\Pi_{A}+\Pi_{B}=\frac{(b-d)^{2}}{4 a}>0
\end{gathered}
$$

The welfare loss $(W L)$ with the Collusion outcome, with respect to the welfare under the perfectly competitive equilibrium is:

$$
\begin{gathered}
W L=\left[b-\frac{(b+d)}{2}\right]\left[\frac{(b-d)}{a}-\frac{(b-d)}{2 a}\right] \\
W L=\frac{(b-d)^{2}}{4 a}
\end{gathered}
$$

\subsection{Threat}

Threat is a conjecture where there is an established firm $A$ that acts as a monopsonist, and another firm $B$ considers entering the market. $A$ increases the wage or expands employment to discourage the entry of $B$, and once $B$ desists from entering the market, $A$ moves back to being a monopsonist. Thus, the Threat equilbrium is the Monopsony equilibrium, which is the Collusion equilibrium, but all the employment is done by firm $A$, and all the profits are for firm $A$.

\subsection{Cournot}

In order to solve the Cournot conjecture, firms are assumed not to cooperate. Firms compete in the quantity of labor that they hire, meaning that they hire the amount of 
labor that maximizes their profits, given the amount of labor hired by their competitor. Each firm takes the labor hired by the other firm, as given. Hiring decisions affect labor prices.

The profit maximization for firm $A$ under Cournot, can be written as:

$$
\begin{gathered}
\Pi_{A}=b l_{A}-\left[d+a\left(l_{A}+l_{B}\right)\right] l_{A} \\
\frac{\partial \Pi_{A}}{\partial l_{A}}=b-d-2 a l_{A}-a l_{B}=0
\end{gathered}
$$

The reaction function (optimal strategy) for firm $A$ is:

$$
l_{A}=\frac{b-d-a l_{B}}{2 a}
$$

By symmetry, the reaction function for firm $B$ is:

$$
l_{B}=\frac{b-d-a l_{A}}{2 a}
$$

Replacing the reaction function of firm $A$, in the reaction function of firm $B$ :

$$
\begin{gathered}
l_{B}=\frac{b-d-a\left[\frac{b-d-a l_{B}}{2 a}\right]}{2 a} \\
l_{B}=\frac{b-d}{3 a}
\end{gathered}
$$

Replacing the optimal demand of labor of firm $B$, in the reaction function of firm $A$ :

$$
\begin{gathered}
l_{A}=\frac{b-d-a\left[\frac{(b-d)}{3 a}\right]}{2 a} \\
l_{A}=\left[\frac{2(b-d)}{6 a}\right]=\frac{b-d}{3 a}
\end{gathered}
$$

Total employment is the sum of the optimal labor demands of $A$ and $B$ :

$$
L=l_{A}+l_{B}=\frac{2(b-d)}{3 a}
$$


The wage is:

$$
w=d+a \frac{2(b-d)}{3 a}=\frac{2 b+d}{3}>0
$$

The mark-down is estimated as the marginal product of labor minus the wage rate over the marginal product of labor, as before:

$$
\begin{gathered}
M D=\left[\frac{b-\left[\frac{2 b+d}{3}\right]}{b}\right] \\
M D=\frac{b-d}{3 b}>0
\end{gathered}
$$

The wage elasticity of supply at equilibrium is calculated as:

$$
\begin{gathered}
\eta=\frac{1}{a} \frac{\frac{2 b+d}{3}}{\frac{2(b-d)}{3 a}} \\
\eta=\frac{2 b+d}{2(b-d)}>0
\end{gathered}
$$

The profits of each firm and the total profits, are:

$$
\begin{gathered}
\Pi_{A}=\Pi_{B}=\left[b-\frac{(2 b+d)}{3}\right] \frac{(b-d)}{3 a} \\
\Pi_{i}=\left[\frac{(b-d)}{3}\right] \frac{(b-d)}{3 a} \\
\Pi_{i}=\frac{(b-d)^{2}}{9 a} \\
\Pi=\frac{2(b-d)^{2}}{9 a}
\end{gathered}
$$

The welfare loss with the Cournot outcome, with respect to the welfare under the perfectly competitive equilibrium is:

$$
\begin{gathered}
W L=\left[b-\frac{(2 b+d)}{3}\right]\left[\frac{(b-d)}{a}-\frac{2(b-d)}{3 a}\right] \\
W L=\frac{(b-d)^{2}}{9 a}
\end{gathered}
$$




\subsection{Stackelberg}

Under the Stackelberg conjecture, firms do not cooperate but rather, compete, with one firm acting as a leader in the demand for labor, and the other firm acting as a follower in the demand for labor. Assume firm $B$ is the leader and firm $A$ is the follower, and takes the quantity of labor hired by firm $B$ as given. Hiring decisions of $A$ and $B$ affect labor prices.

The reaction function for firm $A$ is the same as in Cournot:

$$
l_{A}=\frac{b-d-a l_{B}}{2 a}
$$

Firm $B$ knows it is the market leader, and it is aware that the labor hiring decisions of $A$, depend on its own decision. In fact, $B$ knows the reaction function of $A$. Thus, profit maximization for firm $B$ can be expressed as:

$$
\begin{gathered}
\Pi_{B}=b l_{B}-\left[d+a\left(l_{A}+l_{B}\right)\right] l_{B} \\
\Pi_{B}=(b-d) l_{B}-a\left[\frac{b-d-a l_{B}}{2 a}\right] l_{B}-a l_{B}^{2} \\
\Pi_{B}=(b-d) l_{B}-\left[\frac{(b-d) l_{B}-a l_{B}^{2}}{2}\right]-a l_{B}^{2} \\
\frac{\partial \Pi_{2}}{\partial l_{2}}=b-d-\left[\frac{(b-d)}{2}\right]+\left[\frac{2 a l_{B}}{2}\right]-2 a l_{B}=0 \\
l_{B}=\left[\frac{b-d}{2 a}\right]
\end{gathered}
$$

Replacing the optimal employment of the leading firm $B$, in the reaction function of firm $A$ :

$$
\begin{gathered}
l_{A}=\frac{b-d-a\left[\frac{b-d}{2 a}\right]}{2 a} \\
l_{A}=\left[\frac{(b-d)}{4 a}\right] \\
L=\left[\frac{3(b-d)}{4 a}\right]
\end{gathered}
$$


Thus, the wage rate is:

$$
w=d+a\left[\frac{3(b-d)}{4 a}\right]=\frac{3 b+d}{4}>0
$$

And the mark-down is:

$$
\begin{aligned}
& M D=b-\frac{3 b+d}{4} \\
& M D=\frac{b-d}{4}>0
\end{aligned}
$$

The price elasticity of supply is:

$$
\begin{gathered}
\eta=\frac{1}{a} \frac{\frac{3 b+d}{4}}{\frac{3(b-d)}{4 a}} \\
\eta=\frac{3 b+d}{3(b-d)}>0
\end{gathered}
$$

The profits for $A, B$ and the total profits, are:

$$
\begin{gathered}
\Pi_{A}=\left[b-\left[\frac{3 b+d}{4}\right]\right] \frac{(b-d)}{4 a} \\
\Pi_{A}=\frac{(b-d)}{4} \frac{(b-d)}{4 a} \\
\Pi_{A}=\frac{(b-d)^{2}}{16 a} \\
\Pi_{B}=\frac{(b-d)}{4} \frac{(b-d)}{2 a} \\
\Pi_{B}=\frac{(b-d)^{2}}{8 a} \\
\Pi=\frac{(b-d)}{4} \frac{3(b-d)}{4 a} \\
\Pi=\frac{3(b-d)^{2}}{16 a}>0
\end{gathered}
$$

The welfare loss with the Stackelberg outcome, with respect to the welfare under the perfectly competitive equilibrium is:

$$
W L=\left[b-\frac{(3 b+d)}{4}\right]\left[\frac{(b-d)}{a}-\frac{3(b-d)}{4 a}\right]
$$




$$
W L=\frac{(b-d)^{2}}{16 a}
$$

\subsection{Bertrand}

In Bertrand, firms compete in wages, meaning that they set their wages to maximize their profits, taking the price of their competitor as given. Starting with any wage, for example the Cournot wage, one firm will have the incentive to increase the wage and hire all the workers. But the the other firm will do the same, and hire all the workers. At equilibrium, one or both firms will pay a wage equal to the marginal product of labor, and hire all the workers.

Thus, under the setting of this article, the Bertrand equilibrium replicates the perfect competition equilibrium, since the wage equals the marginal cost of labor and the marginal product of labor.

Profit maximization in Bertrand can be expressed as:

$$
\begin{gathered}
w=b \\
b=d+a L \\
L=\frac{b-d}{a}
\end{gathered}
$$

Since the marginal product of labor is assumed constant in this model, there is no $a$ priori mechanism to allocate labor between firms. However, in a symmetric equilibrium:

$$
\begin{gathered}
l_{A}=l_{B}=\frac{b-d}{2 a} \\
\Pi_{A}=\Pi_{B}=0 \\
M D=0 \\
\eta=\rightarrow \infty \\
W L=0
\end{gathered}
$$

In this case, $\eta$ is infinite because the only price possible for a Bertrand producer is to 
pay the marginal product of labor that equals the marginal cost of labor. Else, the other firm will pay it and the firm will hire no labor. Its residual labor supply is horizontal. And as in perfect competition, firms will have no market power and no profits, and there will be no welfare loss with respect to the competitive equilibrium.

\subsection{Summary}

Graphically a summary of the results obtained in the model can be summarized as shown in figure 1:

Figure 1: Summary of the Results of the Model of Oligopsony

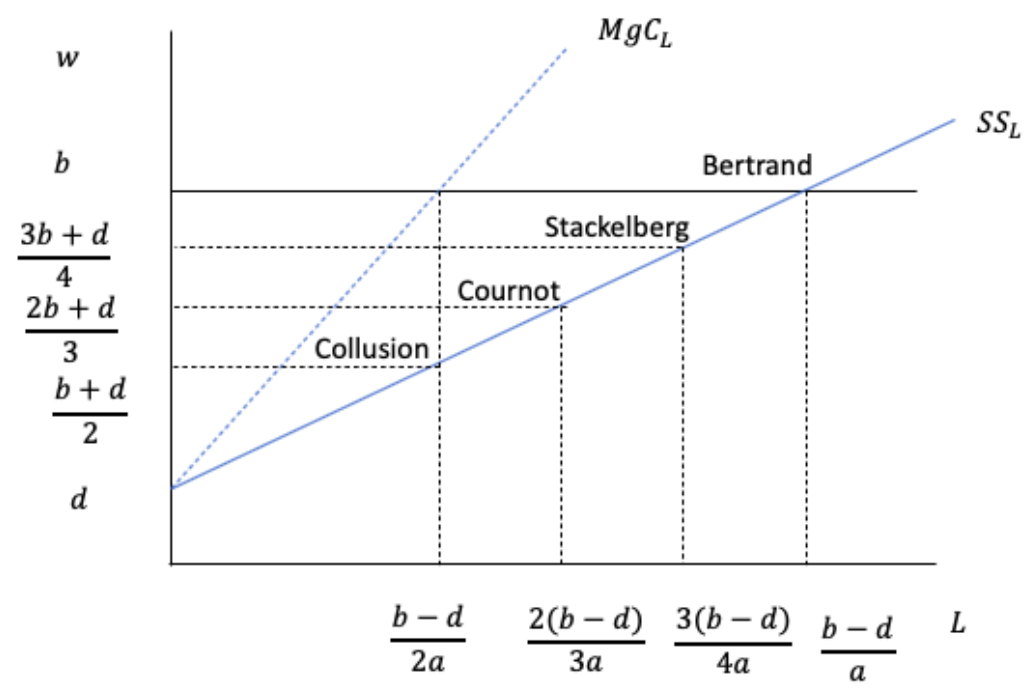

Source: author

A more detailed summary of the results is presented in tables 1,2 and 3: 
Table 1: Summary of the Results of the Oligopsony Model

$\begin{array}{ccccc}\text { Market } & \mathrm{L}_{A} & \mathrm{~L}_{B} & \mathrm{~L} & \text { Wage } \\ \text { Collusion (sym) } & \frac{b-d}{4 a} & \frac{b-d}{4 a} & \frac{b-d}{2 a} & \frac{b+d}{2} \\ \text { Threat } & \frac{b-d}{2 a} & 0 & \frac{b-d}{2 a} & \frac{b+d}{2} \\ \text { Cournot } & \frac{b-d}{3 a} & \frac{b-d}{3 a} & \frac{2(b-d)}{3 a} & \frac{2 b+d}{3} \\ \text { Stackelberg } & \frac{b+d}{2} & \frac{b+d}{4} & \frac{3(b-d)}{4 a} & \frac{3 b+d}{4} \\ \text { Bertrand (sym) } & \frac{b-d}{2 a} & \frac{b-d}{2 a} & \frac{b-d}{a} & b\end{array}$

Table 2: Summary of the Results of the Oligopsony Model

$\begin{array}{cccc}\text { Market } & \Pi_{A} & \Pi_{B} & \Pi \\ \text { Collusion (sym) } & \frac{(b-d)^{2}}{8 a} & \frac{(b-d)^{2}}{8 a} & \frac{(b-d)^{2}}{4 a} \\ \text { Threat } & \frac{(b-d)^{2}}{4 a} & 0 & \frac{(b-d)^{2}}{4 a} \\ \text { Cournot } & \frac{2(b-d)^{2}}{18 a} & \frac{2(b-d)^{2}}{18 a} & \frac{2(b-d)^{2}}{9 a} \\ \text { Stackelberg } & \frac{(b-d)^{2}}{16 a} & \frac{(b-d)^{2}}{8 a} & \frac{3(b-d)^{2}}{16 a} \\ \text { Bertrand (sym) } & 0 & 0 & 0\end{array}$

Table 3: Summary of the Results of the Oligopsony Model

$\begin{array}{cccc}\text { Market } & \text { MD } & \eta & W L \\ \text { Collusion (sym) } & \frac{b-d}{2 b} & \frac{b+d}{b-d} & \frac{(b-d)^{2}}{4 a} \\ \text { Threat } & \frac{b-d}{2 b} & \frac{b+d}{b-d} & \frac{(b-d)^{2}}{4 a} \\ \text { Cournot } & \frac{b-d}{3 b} & \frac{2 b+d}{2(b-d)} & \frac{(b-d)^{2}}{9 a} \\ \text { Stackelberg } & \frac{b-d}{4 b} & \frac{3 b+d}{3(b-d)} & \frac{(b-d)^{2}}{16 a} \\ \text { Bertrand (sym) } & 0 & \rightarrow \infty & 0\end{array}$

Within the simple model structure presented in this article, the algebraic results allow us to conclude unambiguously, that:

Collusion and Threat replicate Monopsony, have the lowest wage; the lowest employment; the lowest wage elasticity of supply; the highest mark-down; the highest profits and the lowest welfare.

When compared to Collusion, Cournot has a higher wage; a higher employment; a higher wage elasticity of supply; a lower mark-down; lower profits and a higher welfare.

When compared to Cournot, Stackelberg has a higher wage; a higher employment; a higher wage elasticity of supply; a lower mark-down, lower profits; and a higher welfare. 
Bertrand has the highest wage; the highest employment; highest wage elasticity of supply; the lowest mark-down; the lowest profits; and the highest welfare, when compared to any of the other conjectural variations considered in this model, and replicates in this case the equilibrium that would prevail under perfect competition.

Thus, in general, the conjectures with the highest wages have the highest price elasticity of labor supply; the highest employment; the highest welfare; and the lowest mark-downs, and vice-versa.

\section{Policy}

Given that except for the Bertrand equilibria, the oligopsony equilibria have markdown and thus are inefficient, it is legitimate to ask what can the Government do to improve the resource allocation in this market structure. To highlight a way in which the model presented can be used to study the impacts of economic policy, consider the application of a minimum wage policy. Assume that there is monopsony or collusion, and that such is the wage the prevails in the market, before the Government sets the minimum wage.

\subsection{Minimum Wage Equal to Wage Under Collusion}

If the Government sets the minimum wage equal to the wage that would prevail in the case of collusion, nothing will happen, as shown in figure 2. 
Figure 2: Oligopsony with Minimum Wage Equal to Wage Under Collusion

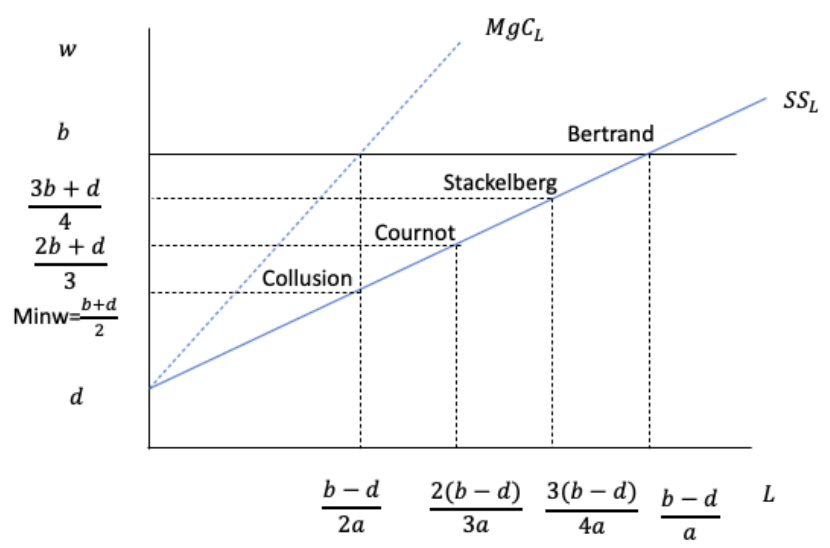

Source: author

\subsection{Minimum Wage Equal to Wage Under Cournot}

If the Government sets the minimum wage equal to the wage that would prevail in the case of Cournot, the level of employment would increase and welfare would increase in the area signalled in green in figure 3.

Figure 3: Oligopsony with Minimum Wage Equal to Wage Under Cournot

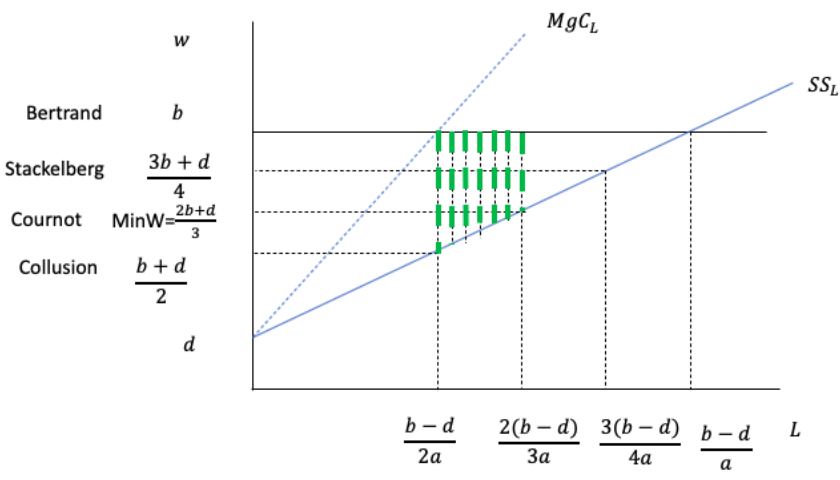

Source: author 


\subsection{Minimum Wage Equal to Wage Under Stackelberg}

If the Government sets the minimum wage equal to the wage that would prevail in the case of Stackelberg, employment would increase and the welfare would increase in the areas signalled in green and red, in figure 4.

Figure 4: Oligopsony with Minimum Wage Equal to Wage Under Stackelberg

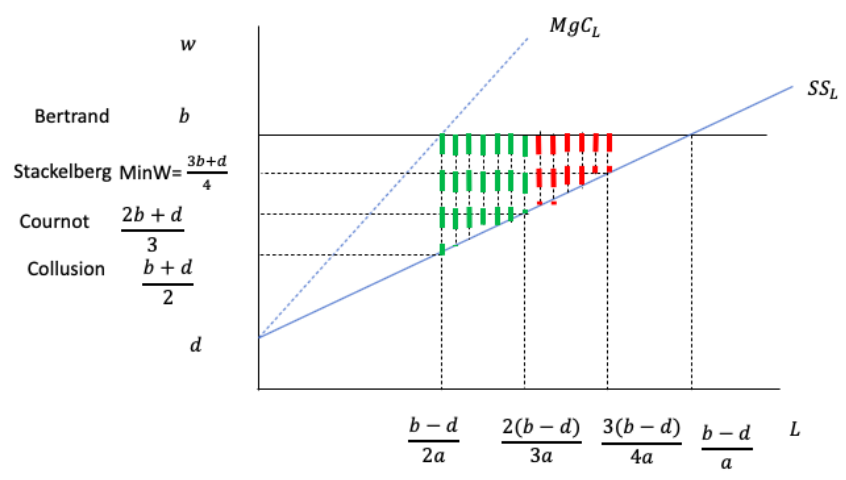

Source: author

\subsection{Minimum Wage Equal to Wage Under Bertrand}

If the Government sets the minimum wage equal to the wage that would prevail in the case of Bertrand, employment and welfare would be maximum and there would be no unemployment. Welfare would increase in the area signalled in green, red and blue, in figure 5 . 
Figure 5. Oligopsony with Minimum Wage Equal to Wage Under Bertrand

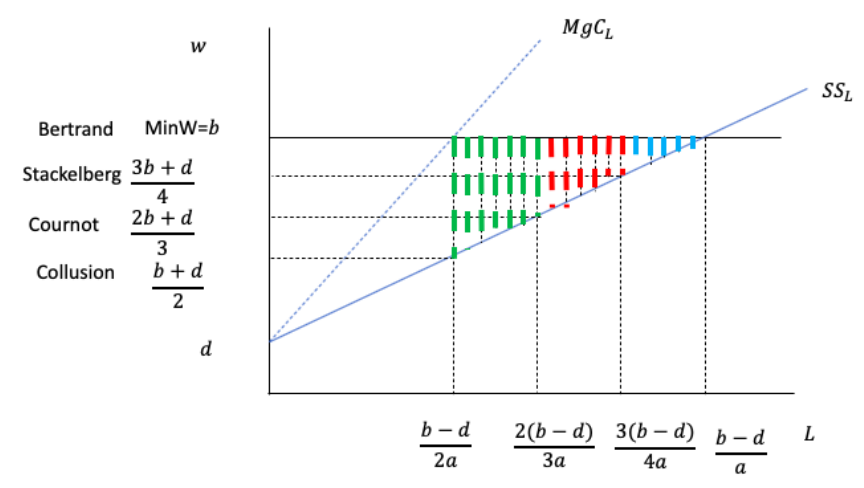

Source: author

If the Government sets a minimum wage above the Bertrand wage, there would be no employment and no welfare in this labor market.

\section{Conclusions}

This article has shown that given the model's assumptions, when firms interact as in Bertrand, they employ more workers and pay higher wages than when they interact as in Stackelberg. When firms interact as in Stackelberg, they employ more workers and pays higher wages than when they interact as in Cournot. And when firms interact as in Cournot, they employ more workers and pays higher wages than when they collude.

In general, the conjectures with the highest wages have the highest price elasticity of labor supply; the highest employment; the highest welfare; the lowest mark-downs, and the lowest profits. And vice-versa.

Starting from monopsony or Collusion in the employment of labor, a minimum wage equal to the Collusion wage, has no impact at all. If it is equal to the Cournot wage, it increases more welfare and employment and reduces profits. If it is equal to the Stackelberg wage, it increases welfare and employment and reduces profits, even more. Finally, if it is equal to the Bertrand wage, it maximizes welfare and employment and reduces profits to zero. 
However, a minimum wage that is higher than the Bertrand wage, generates unemployment and reduces employment, profits and welfare. 


\section{References}

Atkinson, S. E. and Kerkvliet, J. (1989) "Dual Measures of Monopoly and Monopsony Power: An Application to Regulated Electric Utilities", Review of Economics and Statistics,71, 250-257.

Bergman, M.A., Brännlund, R. (1995) "Measuring oligopsony power". Review of Industrial Organinzation 10, 307-321 (1995).

Bhaskar, V., Manning, A. and To, T. (2002), "Oligopsony and Monopsonistic Competition in Labor Markets", Journal of Economic Perspectives, 16 (2), pp. 155-174.

Manning, A. (2003) "2 Simple Models of Monopsony and Oligopsony" Chapter 2 in Monopsony in Motion: Imperfect Competition in Labor Markets, Princeton University Press, pp. 29-55 (27 pages)

OECD (1998), "Buyer Power of Multiproduct Retailers", Policy Roundtables (https : //www.oecd.org/competition/abuse/2379299.pdf, retrieved 13 March 2021)

Rogers, R.T. and Sexton, R. J. (1994) "Assessing the Importance of Oligopsony Power in Agricultural Markets", American Journal of Agricultural Economics, Vol. 76, No. 5, Proceedings Issue (Dec), pp. 1143-1150.

Varian, H. R. (2010) Intermediate Micreoconomics: A Modern Approach Norton, Eighth Edition. 